\title{
KOCAELI, KARAMÜRSEL UZUNDERE (OSMANIYE) KÖYÜ CAMII AHŞAP SÜSLEMELERI
}

Wooden Decorations of Kocaeli, Karamürsel Uzundere (Osmaniye) Village Mosque

\section{Saliha TANIK}

Araş. Gör. Dr., Ankara Hacı Bayram Veli Üniversitesi, Edebiyat Fakültesi Sanat Tarihi Bölümü Ankara / Türkiye.

Research Asistant, Dr., Ankara Hacl Bayram Veli Universty, Faculty of Letters, Department of Art History. Ankara/Turkey.

saliha.tanik@hbv.edu.tr, Orcid: 0000-0002-5406-2608

\author{
Makale Türü / Article Types: Araştırma Makalesi / Research Article \\ Geliş Tarihi / Received: 9 Mart/March 2021 \\ Kabul Tarihi / Accepted: 26 Nisan/April 2021 \\ Yayın Tarihi / Published: 30 Haziran/June 2021 \\ Yayın Sezonu / Pub Date Season: Haziran / June 2021 \\ Cilt / Volume: 19 Sayfa/Pages: 169-193
}

Atıf / Citation: Tanık, Saliha "Kocaeli, Karamürsel Uzundere (Osmaniye) Köyü Camii Ahşap Süslemeleri" [Wooden Decorations Of Kocaeli, Karamürsel Uzundere (Osmaniye) Village Mosque

]". Bozok Üniversitesi llahiyat Fakültesi Dergisi [BOZIFDER]-Bozok University Journal of Faculty of Theology [BOZIFDER]19(Haziran/June 2021): 169-193.

https://doi.org/10.51553/bozifder.893568

Etik Beyan/ Ethical Statement: Bu çalışmanın hazırlanma sürecinde bilimsel ve etik ilkelere uyulduğu ve yararlanılan tüm çalışmaların kaynakçada belirtildiği beyan olunur. / It is declared that scientific and ethical principles have been followed while carrying out and writing this study and that all the sources used have been properly cited (Saliha Tanık).

Intihal / Plagiarism: Bu makale, en az iki hakem tarafından incelendi ve intihal içermediği teyit edildi. / This article has been reviewed by at least two referees and scanned via a plagiarism software. 
$\ddot{\mathrm{O} z}$

Kocaeli ili kapsamındaki tarihi camiler, mimari özellikleri kadar süsleme özellikleri bakımından da dikkat çekmektedir. Makale konumuz Karamürsel Uzundere (Osmaniye) Köyü Camii de bu eserlerden biridir. Karamürsel Uzundere (Osmaniye) Köyü Camii'nde bulunan minber, mihrap, mahfil ve tavan gibi yapı elemanlarındaki ahşap süslemeler Osmanlı'nın geç dönem özelliğini göstermektedir. Sözü edilen cami, 20. yy. başında inşa edilmiştir. Çalı̧̧mamızda, Karamürsel Uzundere (Osmaniye) Köyü Camii, yerinde incelenmiş, fotoğrafları çekilmiş, ölçüleri alınmış ve planı Kocaeli Büyükşehir Belediyesi’nden temin edilmiştir. Camiye ait arşiv kayıt belgeleri Ankara Vakılar Genel Müdürlüğü ve Cumhurbaşkanlığı Osmanlı Arşivi'nden sağlanmışır. Bu araştırmamızda söz konusu caminin yapı elemanlarında bulunan ahşap süslemeleri ele alınacaktır. Süslemelerde teknik olarak oyma, ajur (kafes oyma), çakma ve aplike teknikleri, bezeme öğesi olarak geometrik, nesneli, bitkisel motifler tercih edilmiş ve uygulanmışır. Kocaeli ilinin Karadeniz'e yakın olması nedeniyle, camide kullanılan ahşap bezeme örneklerinin benzerleri daha çok Karadeniz bölgesinde karşımıza çıkmaktadır. Köyün 19. yy. sonunda Kafkasya muhacirleri tarafından kurulduğu göz önünde bulundurulduğunda, Kafkasya'dan gelen yerel usta ve sanatkârlar eliyle cami süslemelerinin yapıldığı tahmin edilmektedir. Buradan hareketle incelediğimiz ahşap bezemelerin, Türk ahşap sanatındaki yeri saptanarak karşılaştırmalı bir tespite gidilecektir.

Anahtar Kelimeler: Türk-İslam Sanatı, Kocaeli, Karamürsel, Cami, Ahşap Süsleme.

\begin{abstract}
Historical mosques in Kocaeli Province attract attention their decorative features as well as their architectural features. Karamürsel Uzundere (Osmaniye) Village Mosque which is the article's subject is one of these works. Wooden decorations in the building elements such as mimbar, mihrāb, mahfil (gathering-place), and ceiling in Karamürsel Uzundere (Osmaniye) Village Mosque show the characteristics of the late Ottoman period. The mentioned mosque was built at the beginning of the $20^{\text {th }}$ century. In our study, the Karamürsel Uzundere (Osmaniye) Village Mosque was examined on-site, its photographs were taken, its measurements were made, and its plan was obtained from Kocaeli Metropolitan Municipality. Archive registration documents of the mosque were obtained from Ankara General Directorate of Foundations and Presidency Ottoman Archives. In this research, the wooden decorations in the building elements of the mosque will be discussed. Carving, openwork (lattice carving), repousse, and applique as technique were applied in decorations; also, geometric, object, and vegetable motifs as decoration item were preferred and applied. Similar examples of wooden decoration ones used in the mosque are mostly seen in the Black Sea Region since Kocaeli Province is close to the Black Sea. Considering that the village was founded by Caucasian immigrants at the end of the $19^{\text {th }}$ century, it is estimated that mosque decorations were made by local artisans and craftsmen from the Caucasus. Thus, the importance of wooden decorations, examined by us, in Turkish wooden art will be determined, and a comparative determination will be carried out.
\end{abstract}

Keywords: Turkish-Islamic Art, Kocaeli, Karamürsel, Mosque, Wood(en) Decoration.

\title{
Giriş
}

İzmit Körfezi'nin güneyinde yer alan Karamürsel, Kocaeli ilinin bir ilçesidir. Karamürsel, Antik çağlardan beri bir kıyı yerleşimi olarak varlığını devam ettirmiş, bu özelliğini günümüzde de sürdür- 
mektedir. Antik Çağ'da "Prainetos" veya "Prietos" olarak adlandırılan kentin Bthynia Bölgesi sınırları içinde yer aldığı ve MÖ 63 yılında Roma egemenliğine girdiğ $i^{2}$ bilinmektedir. Doğu Roma döneminde Nikaia'ya 28 mil uzaklıkta yer alan kent $^{3}$ aynı zamanda Nikaia'dan (İznik) Constantinople’a (İstanbul) doğru giden yol güzergâhındadır.

Orhan Gazi'nin 14. yy.'da İzmit ve çevresinin fethi sırasında, Kara Mürsel Alp ${ }^{4}$, şehrin fethiyle görevlendirilmiş, fetih sonrasında kasaba Kara Mürsel Alp tarafindan kurulmuştur ${ }^{5}$. Fetihten sonra Alp Gazi, kendisine tımar verilen kasabanın, günümüzde Pazarköy (Pazar Yeri) olarak adlandırılan güney yakadaki yerleşimine iskân etmiş ve Karamürsel'de ilk Osmanlı donanmasını kurmuştur $^{6}$ (Harita 1).

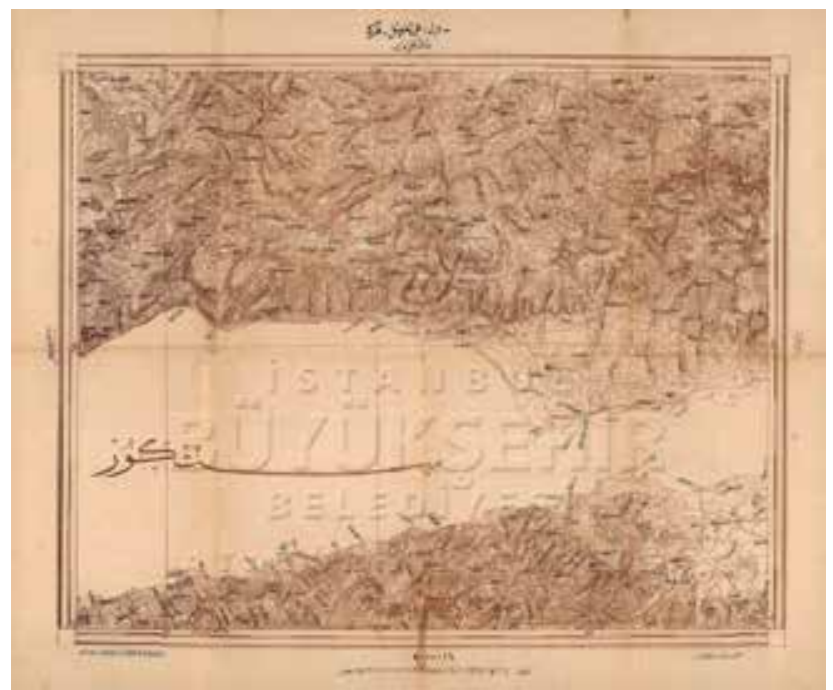

Harita 1: Osmanlı Haritasında Karamürsel ve Çevresi (İBB/Atatürk Kitaplı̆̆1)

1 Mitchel Ramsay, Anadolu’nun Tarihi Coğrafyası, çev. M. Pektaş (İstanbul: Milli Eğitim Basımevi, 1960), 19.

2 Bülent Öztürk, "Karamürsel'de (Bthynıa) Bir Antik Kıyı Yerleşimi: Preınetos/Preıetos", Uluslararası Karamürsel Alp ve Kocaeli Tarihi Sempozyum Bildirileri, ed. Haluk Selvi vd. (Kocaeli: Kocaeli Büyükşehir Belediyesi Yayınları, 2016), 1/64.

3 Ramsay, Anadolu'nun Tarihi, 205.

4 Karamürsel Alp’in Türk asıllı olduğu, doğum ve ölüm tarihlerinin bilinmediği belirtilmiştir. (Daha geniş bilgi için bk. Agâh Yönsel- Şemsettin Arkan, Karamürsel (Ankara, 1972), 21.

5 Erdoğan Özdemir, Dünden Bugüne Karamürsel (Kocaeli: Karamürsel Belediyesi Kültür Yayınları, 1994), 29.

6 Özdemir, Dünden Bugüne, 34. 
Karamürsel şehri, denizcilik faaliyetlerine ek olarak gerek İpek Yolu güzergâhında yer alması gerekse güzergâhın hac yolunu da kapsaması nedeniyle canlılık kazanmış ve ticari faaliyetler artmışııํ. Bunun yanında Karamürsel'in meyve ve sebzecilik gibi tarımsal faaliyetlerinin, Osmanlı ekonomisine canlılık kazandırdığı, özellikle İstanbul ve saray çevresinin günlük sebze ve meyve ihtiyacının bu bölgeden sağlandığ1 bilinmektedir'. 18. yy.'in başlarında ipek ticaretine geçiş yapan Osmanl1 İmparatorluğu'nda dut yetiştiriciliği artmış, söz konusu şehirde de bu tarihten sonra ipekböceği yetiştiriciliği yaygınlaşmış ve bu konuda eğitim için Fransız tüccarlardan bilgi edinilmiştir9. Şehirde ipekböceği yetiştiriciliğine bağlı olarak bir dokuma fabrikasının kurulduğu plaj yolundaki fabrika bacası kalıntısından anlaşılmaktadır. Günümüzde, sözü edilen fabrika bacası, Kocaeli K.K.T.V.K.B.K.'nın 09.03.2000 tarih 5535 sayılı kurul kararıyla tescillenmiştir.

19. yy.'da şehri ziyaret eden Şemseddin Sami, buradaki dokuma fabrikasında çuha ve kazmir (kaşmir) kumaşlarının dokunduğunu belirtmektedir ${ }^{10}$. 93 Harbi adıyla bilinen 1877-1878 Osmanl1-Rus Savaş1, İmparatorluğun genelinde olduğu gibi Karamürsel'de de nüfus, ticaret ve kültürel yönden değişiklikler meydana getirmiştir. Savaşın sona ermesiyle kaybedilen topraklardan gelen Müslüman muhacirler Kocaeli'nin çeşitli yerleşim yerlerine dağılarak buraları kendilerine yurt edinmişlerdir. Bu dönemde Kocaeli bölgesine yerleşen Kafkas göçmenlerinin sayısının 15.000 civarında olduğu ifade edilmektedir ${ }^{11}$. Karamürsel'e bağlı Uzundere (Osmaniye) Köyü'nün de bir Kafkas göçmen köyü olduğu belirtilmektedir ${ }^{12}$. Uzundere (Osmaniye) Köyü,

\footnotetext{
7 a.mlf., Kaptan-ı Derya Karamürsel (İstanbul: Zinde Yayıncılık, 2017), 66.

8 Özdemir, Kaptan-ı Derya, 83.

9 Mehmet Kaya- Derya Gecili, “19.Yüzyıl Karamürsel Kazası'nın Sosyo ve Ekonomik Durumu: Temettuat Defterleri Örneği”, Uluslararası Karamürsel Alp ve Kocaeli Tarihi Sempozyum Bildirileri, ed. Haluk Selvi vd. (Kocaeli: Kocaeli Büyükşehir Belediyesi Yayınları, 2016), 1/603.

${ }^{10}$ Şemseddin Sami, "Karamürsel”, Kamusu'l Âlâm (İstanbul: Mihran Matbaas1, 1896), 5/3647.

${ }^{11}$ Feyzullah Yavuz Ulugün, "Kocaeli'de Tarihsel Göçler”, Uluslararası Akçakoca Sempozyumu ve Kocaeli Tarihi Sempozyum Bildirileri, ed. Haluk Selvi vd. (Kocaeli: Kocaeli Büyükşehir Belediyesi Kültür Yayınları, 2015), 3/1283.

${ }^{12}$ Hasan Yüksel, “Kafkas Göçmen Vakıfları”, OTAM (Ankara Üniversitesi Osmanlı Tarihi Uygulama ve Araştırma Merkezi Dergisi) 5/5 (1994), 487.
} 
cami vakfiyesinde ${ }^{13}$ "Uzundere nâm-ı diğger Osmaniye Köyü” olarak, daha geç tarihli arşiv belgesinde ${ }^{14}$ ise sadece “Osmaniye Köyü” şeklinde geçmektedir (Harita 2).

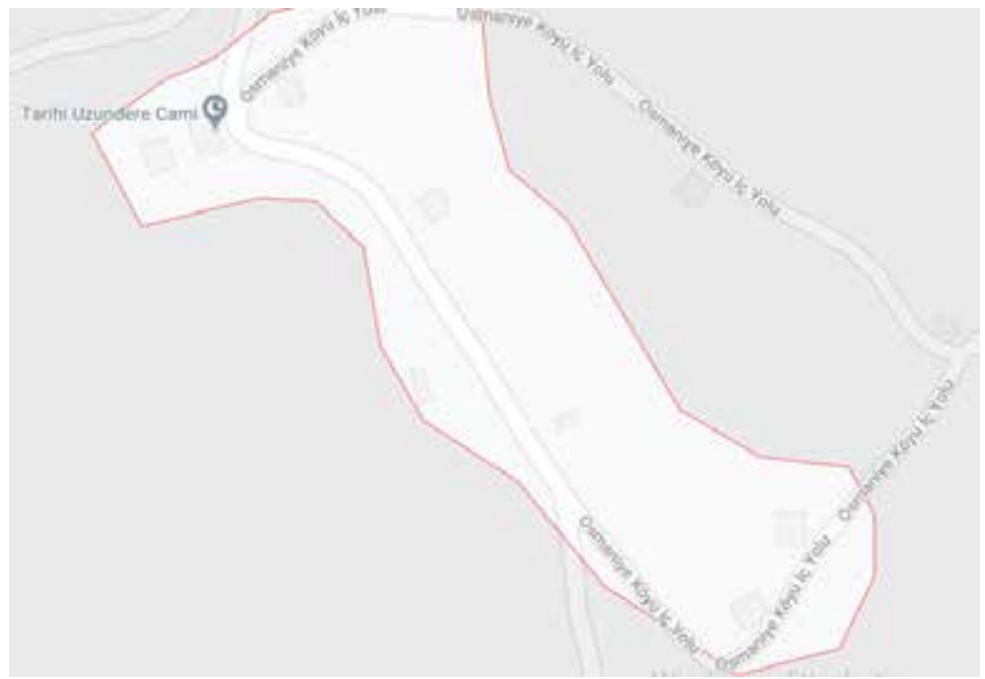

Harita 2. Karamürsel Uzundere (Osmaniye) Köyü İç Yolu (Google Maps-Erişim tarihi 26.02.2021)

\section{Genel Mimari Tanımı}

Caminin vakfiyesinden edinilen bilgiye göre ${ }^{15}$, yapının Batum muhaciri Şaban oğlu Mahmut'a ait nükud-u vakıf olduğu (nakit para verilerek kurulan vakıf) ve köy ahalisi tarafından ilk olarak H 20 Şevval 1305 (M 30 Haziran 1888) tarihinde yapıldığ zaman içinde caminin köy ahalisinin isteği üzerine yeniden inşa edildiği H 14.02.1323 (M 20.04.1905) tarihli belgede belirtilmektedir ${ }^{16}$. Bunun nedeninin, 1894 senesinde meydana gelen İstanbul depreminde, caminin ağır hasar alarak kullanılamayacak hale gelmiş olduğu düşünülebilir. M 1905 yılında yeniden inşa edilmeye başlanıp inşaatı yarıda kalan yapı Sultan II. Abdülhamit tarafından tamamlanmışıır ${ }^{17}$.

13 (V.G.M.A, Defter No: 590., Sayfa No: 6, Sıra No: 5). H 20 Şevval 1305, M 30 Haziran 1888.

14 (DH. MKT, No: 948, Gömlek No: 5). H 14 Safer 1323, M 20 Nisan 1905.

15 (V.G.M.A. Defter No: 590., Sayfa No: 6, Sira No: 5).

16 (DHMKT, No: 948, Gömlek No: 15).

17 Aydın Talay, Eserleriyle ve Hizmetleriyle II. Abdülhamit (İstanbul: Ensar Neşriyat, 2016), 455. 
Cami, 6.90x10.05 m iç ölçülerinde kuzey-güney yönünde dikdörtgen planlıdır. Mihrap, dışa çıkıntılı dikdörtgen kütle biçimindedir. Harimin kuzeyinde doğu-batı yönlü dikdörtgen planlı son cemaat yeri bulunur. Minare yeni bir unsur olup, güneybatı köşede caminin duvarlarından bağımsız olarak konumlanmıştır. Cami, beton sıvalı bir subasman kaide üzerinden yükselmektedir. Harim ve son cemaat yeri içten düz ahşap tavanla, dıştan Marsilya tipi kırma kiremit kaplı dört yöne eğimli çatıyla örtülüdür. Harimin tavanının ortasında kaburgalı bağdadi kubbe meydana getirilmiştir (Çizim 1., Resim 1-2). Cami, K.K.T.V.K.B.K.'nın 24/10/2017 tarih ve 3208 sayıl1 kararı ile tescil edilmiştir.
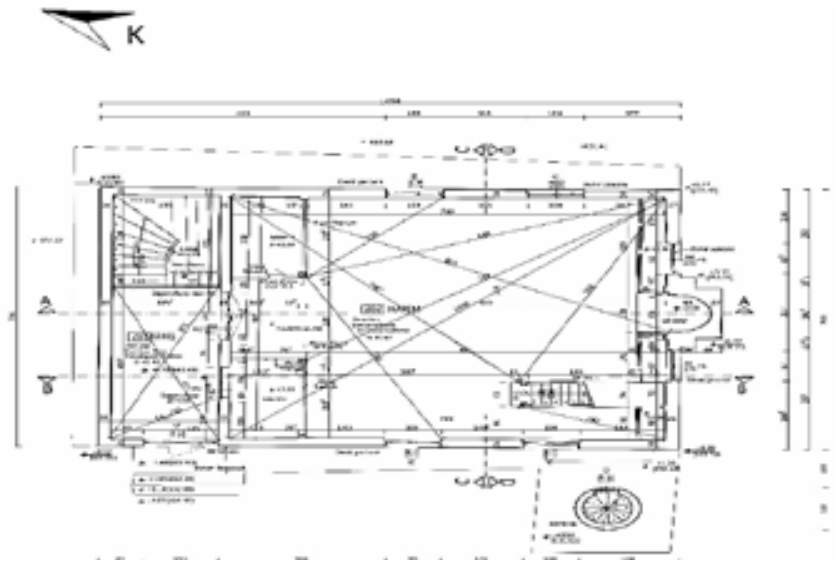

Çizim 1: Uzundere (Osmaniye) Köyü Camii Planı (Şenol Mimarlık-KBB)

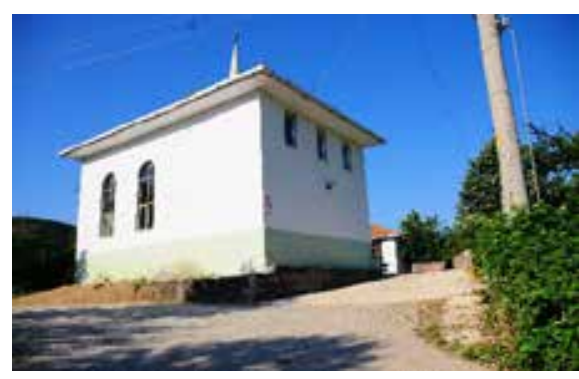

Resim 1. Uzundere (Osmaniye) Köyü

Camii Genel Görünüş Son Cemaat Yeri

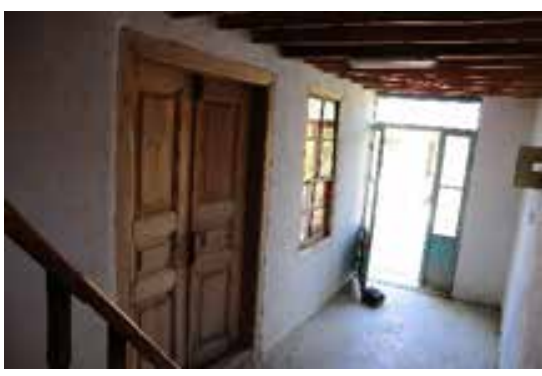

Resim 2. Uzundere (Osmaniye) Köyü Son Cemaat Yeri 


\section{Camideki Ahşap Süslemeler}

Karamürsel Uzundere (Osmaniye) Köyü'nün, ormanlık bir alanda bulunması nedeniyle camide ahşap malzemeden bolca faydalanılmışır. Günümüzde yapı kum ve çimento karışımlı sıva üzerine boyalı olduğu için asıl yapı malzemesi kesin olarak bilinmemektedir. Ancak, sanat tarihi raporunda ${ }^{18}$ caminin hımış teknikli (ahşap karkas arasında kerpiç veya tuğla) olabileceği tahmininde bulunulmaktadır.

Uzundere (Osmaniye) Köyü Camii'ndeki ahşap süslemeler minber, mahfil, mihrap, harim ve mahfil tavanında görülmektedir. Ahşap yüzeylere, oyma, kafes oyma (ajur), çakma ve aplike süsleme tekniklerinin uygulandığ1 anlaşılmaktadır. Süsleme konusu olarak bitkisel motiflerden; C ve S kıvrımlı dallar, yaprak, kır çiçekleri, palmet ve lale; geometrik motiflerden "C" kıvrımı, yıldız, ay-yıldız, baklava dilimi, daire, dilimli madalyon, güneş kursu, ok ucu, yürek ve zikzak; nesneli motiflerden ise yelpaze bezemeleri tatbik edilmiştir. Süslemelerin üzerinde yeşil ve kahverengi tonlarda kök boyası uygulanmıstır.

Ahşap süslemeler en yoğun biçimde yapının güneybatı köşesinde yer alan ahşap minberde görülmektedir (Resim 3., Çizim 2). Oyma tekniğiyle yapılmış ahşap süslemeli parçaların minberin aynalık ve köşk alt1 bölümüne çivi ile çakıldığı anlaşılmaktadır. Minberin dikdörtgen açıklık şeklinde düzenlenen giriş kapısının tepelik kısmında kafes oyma (ajur) tekniğinde barok tarzı ahşap süsleme bulunmaktadır. Kıvrımlı dallar alttan ve üstten dolanarak girift bir kompozisyon meydana getirmektedir. Tepelik altında sarkıt biçimli süsleme iki sıra şeklinde tasarlanmıştır. Üst sıradaki palmet motifleri ve alt sıradaki yarım daireden oluşan süsleme kompozisyonu kafes oyma (ajur) tekniğinde düzenlenmiştir (Resim 4., Çizim 3).

${ }^{18}$ Elif Sağdıç, Karamürsel Osmaniye Mahallesi Osmaniye (Uzundere) Camii Sanat Tarihi Raporu (Nisan 2019). 


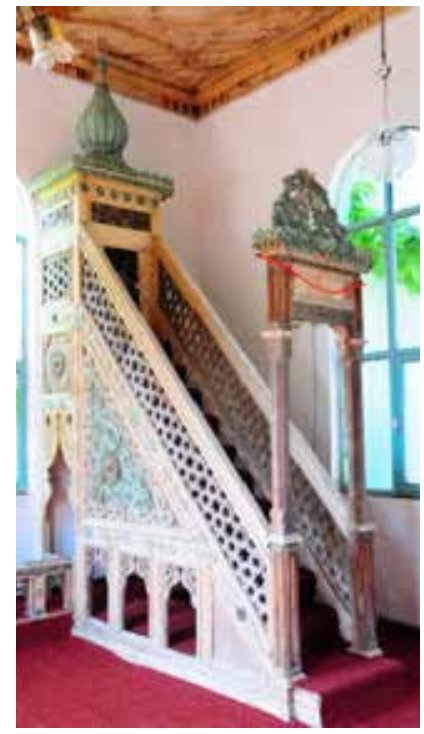

Resim 3. Uzundere (Osmaniye) Köyü Çizim Camii Minberi (Genel Görünüm)

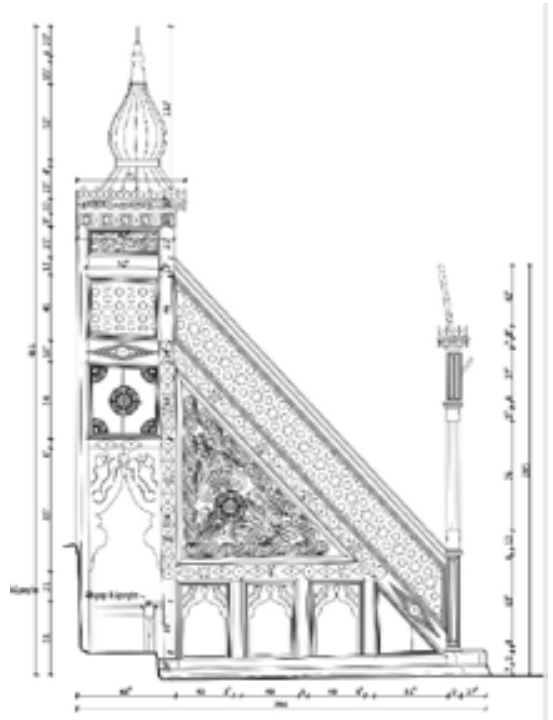

Çizim 2. Genel Çizimi (Şenol Mim-KKB)

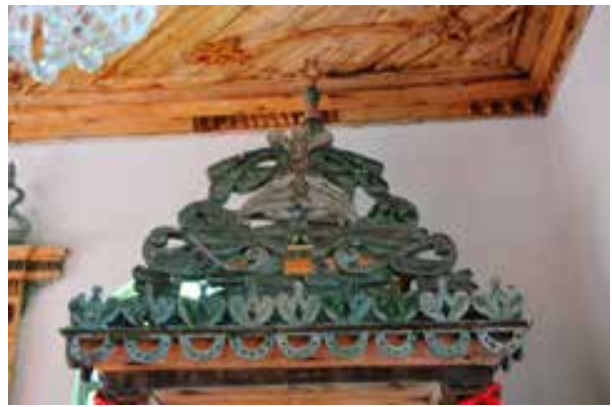

Resim 4. Uzundere (Osmaniye) Köyü Camii Tepelik Kısmı (Detay)

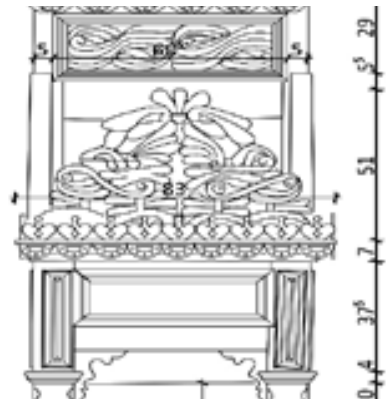

Çizim 3. Tepelik Kısmı Çizimi (Detay) (Şenol Mimarlık-KBB)

Minber aynalığının merkezinde bir güneş kursu yer almaktadır. Güneş kursunun üçgen alanına yeşil renge boyanmış "S" kıvrımlı dallar ve boşluklara volüt biçimli dilimli yapraklar uygulanmıştır. Aynalığın etrafındaki "S" kıvrımlı dallar ortadaki süslemeyi çevrelemektedir. Aynalığ1 kuşatan bordürdeki baklava dilimleri, zikzak ve daire motifleri çakma tekniğiyle yüzeye yerleştirilmiştir. Korkuluk kısmında, kafes 
oyma (ajur) tekniğinde yapılmış, merkezde 6 köşeli yıldızdan gelişen 6 kollu yıldızların kırık hatlarla sonsuzluk prensibi içinde tekrarlandığı bir süsleme yer alır (Resim 5., Çizim 4).

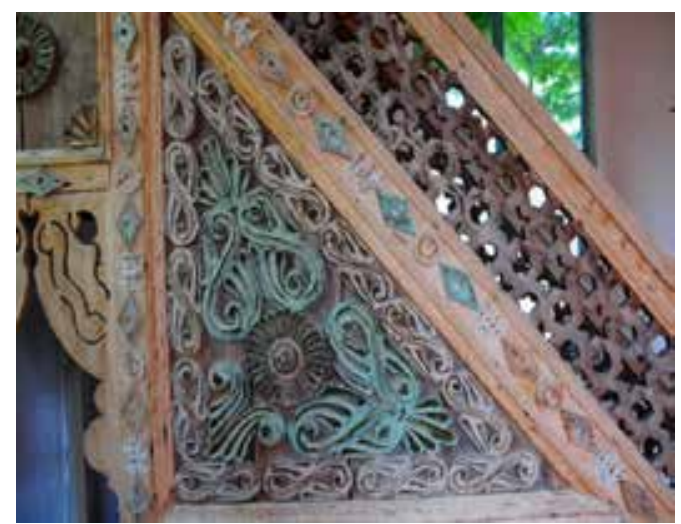

Resim 5. Uzundere (Osmaniye) Köyü Camii Minberi Aynalık ve Korkuluk Kism1
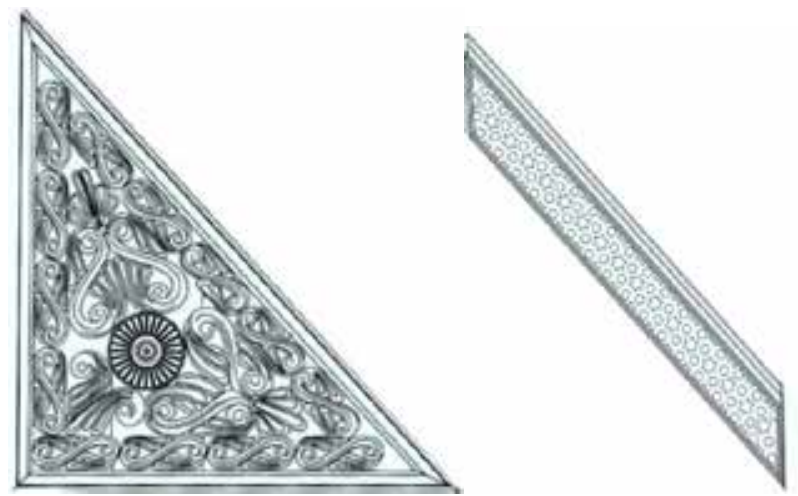

Çizim 4. Aynalık ve Korkuluk Çizimi (Detay)

Camii Minberi Aynalık ve Korkuluk Kısmı (Şenol Mimarlık-KBB)

Minberin doğu cephesindeki köşk altı süslemelerine batı cephesinde rastlanmamaktadır. Minberin batı cephesi bu bakımdan oldukça sade tutulmuştur. Köşk altının üst sırasında yer alan kare bir alanın yüzeyi merdiven korkuluğundaki gibi kafes oyma (ajur) tekniğinde düzenlenmiştir. Alt sıradaki dikdörtgen pano yüzeyine çakma tekniğinde 28 dilimli güneş kursu ve köşelerde çeyrek daire yelpazeler yerleştirilmiş- 
tir. Köşk altı bölümlerinin iri bir baklava dilimiyle ayrıştırıldığı gözlemlenmiştir. Geçit kısmı dekoratif kemerli olarak estetik bir görünüm sergilemektedir (Resim 6., Çizim 5).

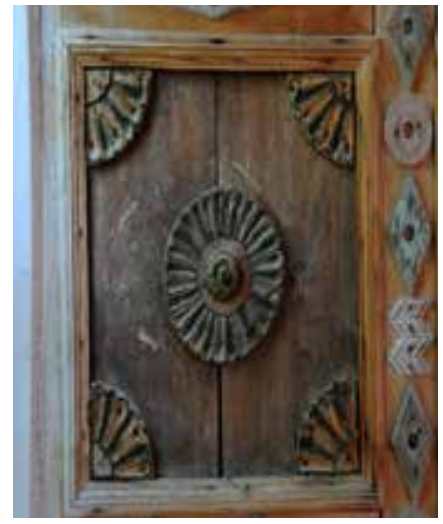

Resim 6. Köşk Altı Bölümü (Detay)

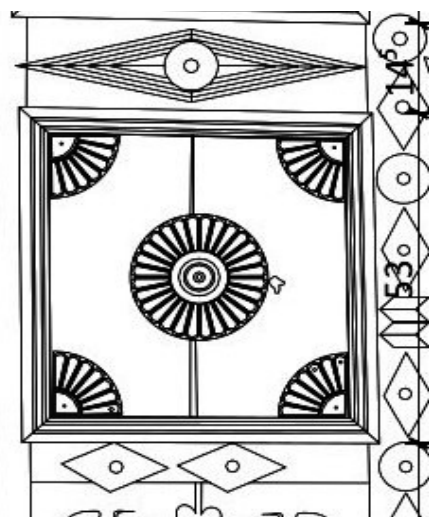

Çizim 5. Köşk Altı Bölümü Çizimi (Şenol Mim-KBB)

Baldaken tipindeki köşk bölümünün yüzeylerinde silmelerin çevrelediği dikdörtgen bir alan içinde kafes oyma (ajur) teknikli "S" kıvrımlı dallar işlenmiştir. Köşk bölümünün üst kısmını sınırlandıran bordürde ay-yıldız motiflerinin yüzeye çakılarak peş peşe sıralandığ görülmektedir. Kapı tepeliğinde yer alan sarkıt biçimli süslemeler aynı şekilde külah altında da düzenlenmiştir. Minberin armudi biçimli külahı ise lale biçimli bir aleme sahiptir (Resim 7).

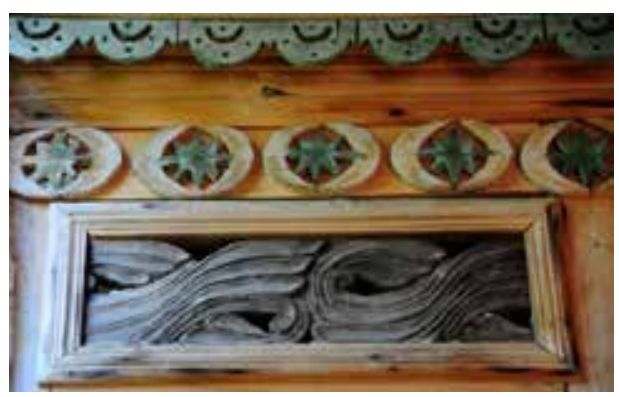

Resim 7. Uzundere (Osmaniye) Köyü Camii Minberi Köşk Bölümü (Detay) 
Kıblenin orta aksında yer alan dışa taşkın mihrabın niş ve aynalık kısmı çimento sıvanın üzerine plastik boya ile boyanmış olup sütunçe ve tepelik kısmı ahşap malzemelidir. Sütunçe ve kaide kısmı yivlidir. Aynalık kısmının yan kenarlarındaki kare birer pano içinde dilimli madalyonlar meydana getirilmiştir. Tepeliğin iki yanında ise palmet motifli alemler yer almaktadır (Resim 8, 9). Mihrap sekisinin doğu ve batı yöndeki ahşap korkuluğunda uygulanan kaş kemerli açıklıkların kenarlarında kafes oyma (ajur) teknikli beş köşeli yıldız motifi, üst ve yan kenarlardaki boşluklarda ise minberde görülen zikzak ve baklava dilimleri bulunmaktadır (Resim 10).

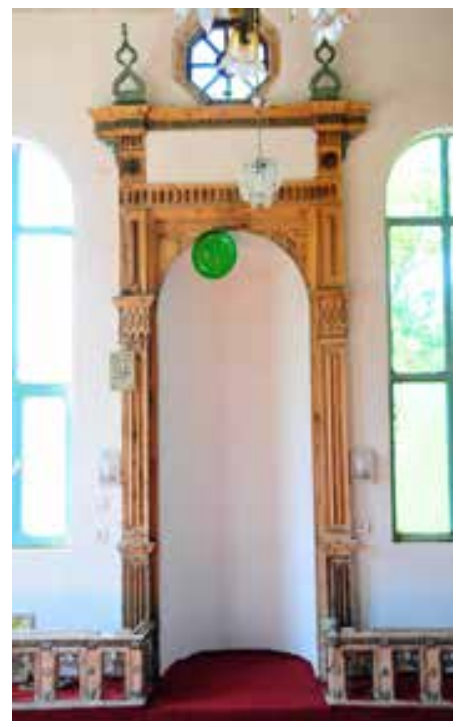

Resim 8. Uzundere (Osmaniye) Köyü Camii Mihrabı

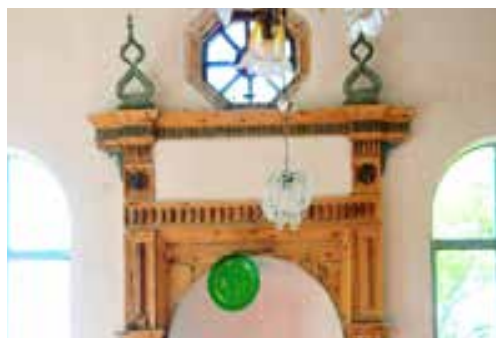

Resim 9. Mihrap (Detay) 


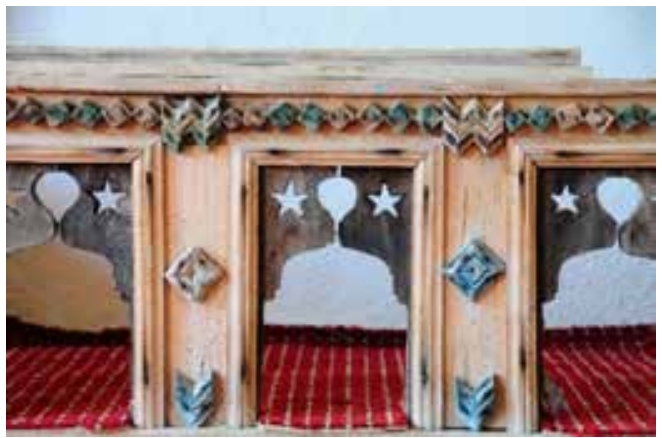

Resim 10. Uzundere (Osmaniye) köyü Camii Mihrap Sekisi Korkulu$\breve{g u}$ (Detay)

Kuzey duvarda, doğu-batı duvarlara bitişik olarak uzanan kadınlar mahfili ahşap ve iki katlı olarak düzenlenmiştir (Resim 11). Kaideden itibaren pahlanarak çokgen forma dönüşen alt kattaki ahşap dikmelerin kübik başlıkları geometrik bezemelidir. Kafes oyma (ajur) teknikli "C" kıvrımlı konsollar mahfil tabanı altındaki boşluklarda yer almaktadır. Konsolların arasında ucu boğumlu vidalarla sonlanan sarkıt niteliğinde yarım yelpaze motifleri görülmektedir (Resim 12).

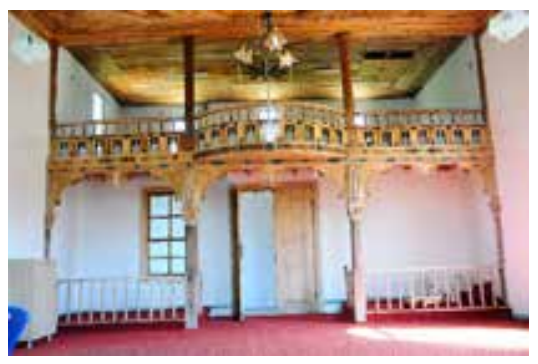

Resim 11. Uzundere (Osmaniye) Köyü Camii Kadınlar Mahfili (Genel Görünüm)

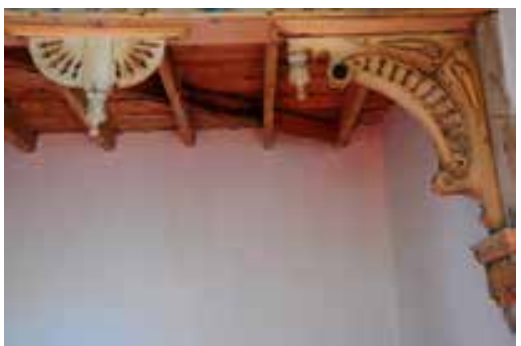

Resim 12. Mahfil Taban Altı (Detay)

Mahfil alt katını üst katından ayıran bordürde baklava dilimleri, büyük ve küçük dönüşümlü olarak sıralanmıştır. Mahfil korkuluğunu saran bordür yüzeyinde ise minber ve mihrap sekisi korkuluğundaki zikzak motifinin bir benzerinin uygulandığı görülmektedir. Mahfil 
korkuluğu iki sıra şeklinde tasarlanmıştır. Alt sıra korkuluktaki kaval silmelerin çevrelediği dikdörtgen açıklıklıklarının üst kısmında kafes oyma (ajur) teknikli yürek motifi oluşturulmuştur. Yürek motifinin kenarlarında boyalarla yapılmış altı köşeli yıldızların, sadece birkaçında tasvir edildiği gözlenmiştir. Diğer yıldız tasvirlerinin zaman içinde silinmesi muhtemeldir. Mahfil çıkması üzerindeki dikdörtgen açılıklarının birinde caminin onarım tarihini belirten Arapça ve Türkçe rakamlar bulunmaktadır. Üst sıra korkuluğu ise ahşap parmaklıklı olarak tasarlanmıştır (Resim 13., Çizim 6).

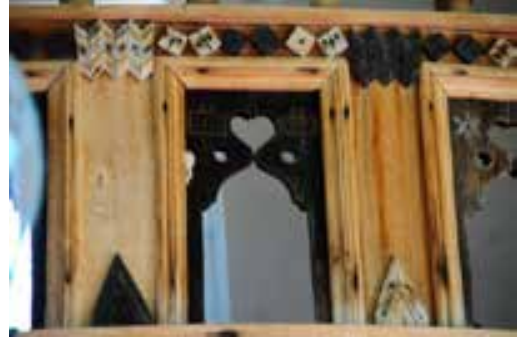

Resim 13. Uzundere (Osmaniye Köyü) Camii Mahfil Korkuluğu (Detay)

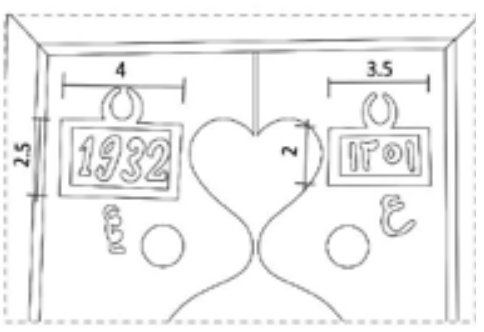

Çizim 6. Mahfil Korkuluğu (Detay) (Şenol Mimarlık-KBB)

Mahfil tavanında, merkezde kabartma dilimli bir kabaradan çevreye yayılan uçları palmet motifi ile biten sekiz kollu yıldız motifi bulunmaktadır (Resim 14). Harimin düz ahşap tavanı ise geometrik şekillerle hareketlendirilmiştir. Sekizgenin ortasındasındaki kare alan içine kaburgalı bağdadi bir kubbe yerleştirilmiştir. Silmelerin kuşattığı kare alanın dört köşesindeki aplike edilmiş ok uçlu çıtalar merkezden çevreye doğru yayılım göstermektedir. Sekizgenin köşelerindeki merkezde yer alan madalyon motifi, çevresindeki "S" ve "C" kıvrımlı dallarla tavana monte edilmiştir. Kalan üçgen alanlarda üçgen biçimli profillerin uçları palmet motifiyle sonlanarak bir kompozisyon oluşturulmuştur. Kaburgalı bağdadi kubbenin göbeği ise sekiz kollu ahşap bir yıldızla vurgulanmıştır (Resim 15, 16, 17., Çizim 7). 


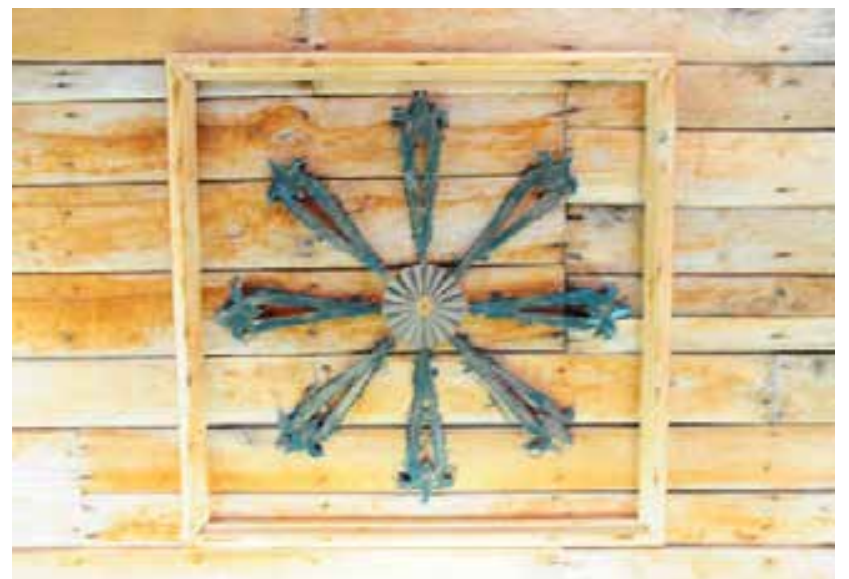

Resim 14. Uzundere (Osmaniye) Köyü Camii Mahfil Tavanı (Detay)

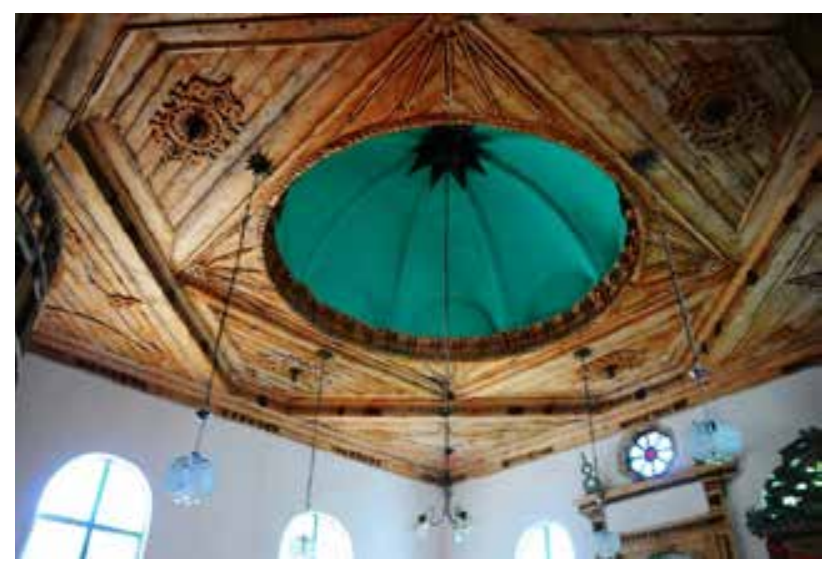

Resim 15. Uzundere (Osmaniye) Köyü Camii Harim Tavanı (Genel)

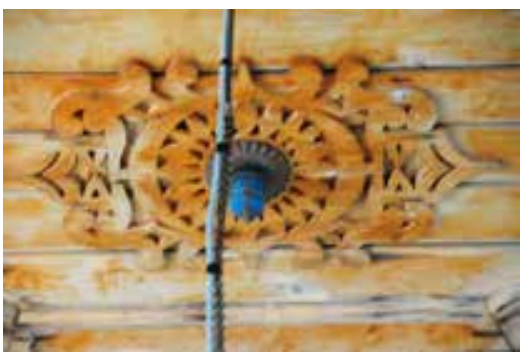

Resim 16. Harim Tavanı (Detay)

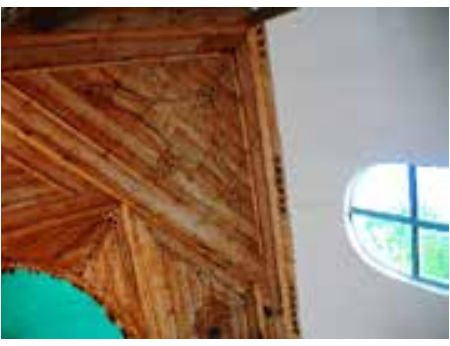

Resim 17. Harim Tavanı (Detay) 


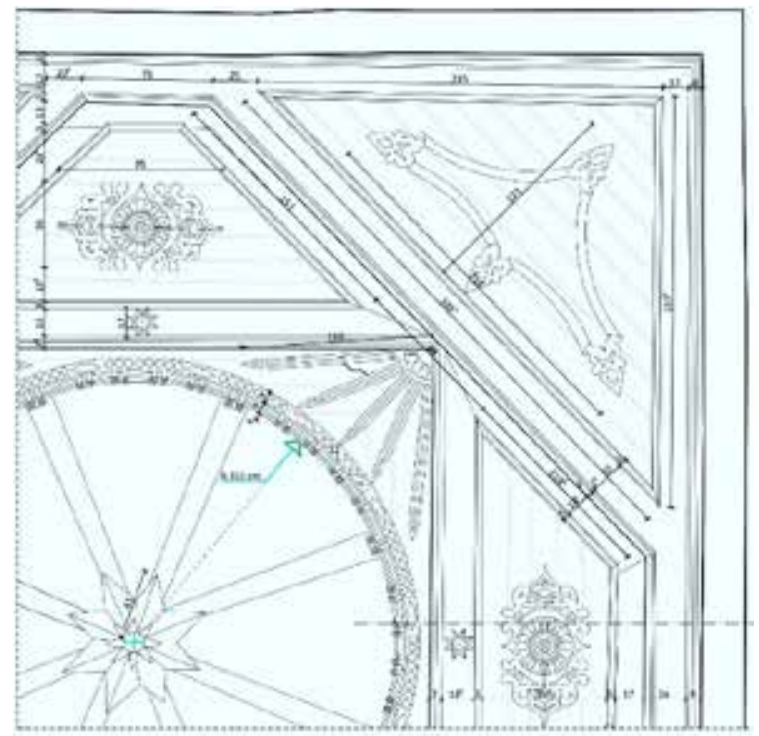

Çizim 5. Harim Tavanı-Detay (Şenol Mimarlık-KBB)

\section{Değerlendirme ve Karşılaştırma}

Türk sanatında ahşabın camilerde kullanımı oldukça eski tarihlere dayanmaktadır. Gazneliler dönemine ait ağaç direkler üzerindeki ahşap çatılı Arusü'l-Felek Camiii ${ }^{19}$, günümüzde tek ağaç sütunu kalan Oburdan ve Kurut camilerine ek olarak 24 ağaç sütunlu Hive Mescid-i Cumasi $^{20}$, Orta Asya Türk dönemi ahşap camili geleneğinin öne çıkan eserleridir. Anadolu Selçukluları zamanında ahşap, Orta Asya ekolünü devam ettirerek kendine özgü yeni bir kimlik kazanmıştır. Anadolu Türk mimarlığında Sivrihisar Ulu Camii (1274), Afyon Ulu Camii (1273), Ankara Arslanhâne Camii (1289-1290) ve Eşrefoğlu Camii (1299) ahşap direkler üzerine kirişlemeli ahşap tavanlarıyla bilinmektedir ${ }^{21}$. Anadolu Selçuklu döneminde kullanılan minberler de çoğunlukla ahşap malzemeden yapılmışıı²2 ${ }^{22}$ Anadolu'da ilk ahşap malzemeli

19 Oktay Aslanapa, Türk Sanatı (İstanbul: Remzi Kitabevi, 1989), 43.

20 Aslanapa, Türk Sanat, 131.

${ }^{21}$ Gönül Öney, Anadolu Selçuklu Mimari Süslemesi ve El Sanatları (Ankara: Türkiye İş Bankası Kültür Yayınları, 1992), 141-142.

${ }^{22}$ Ali Boran, Anadolu'daki $\dot{I}_{c ̧}$ Kale Cami ve Mescitleri (Ankara: TTK, 2001), 238. 
minberin Konya Alâeddin Camii minberi olduğu belirtilmektedir ${ }^{23}$. Bunun haricinde Selçuklu döneminde kündekâri, eğri kesim, oyma, tarsi, maşrabiye teknikleri kullanılarak ahşap sanduka, kapı ve pencere kanatlarında süslemeler uygulandığ1 görülmektedir ${ }^{24}$.

Orhan Gazi döneminde özellikle Düzce ve Kocaeli-Kandıra çevresinde çandı tipi denilen ahşap yığma teknikli camilerin inşa edildiği bilinmektedir ${ }^{25}$. Kandıra çevresindeki günümüze ulaşabilmiş çandı tipi camilerin, üç köyün birleşim bölgesi olan divan köylerinde yer aldıkları tarafımızca tespit edilmiştir. 15. yy.'a ait Osmanlı dönemi Ayaş Ulu Camii ve Ahi Elvan Camii örnekleri ise ahşap direkli olup Selçuklu camilerinin devamı niteliğindeki özgün eserlerdir ${ }^{26}$. 16. yy.'da ahşap süslemelerde Selçuklu geleneği devam ederken, klasik bir üslubun belirlendiği de anlaşılmaktadır. Bu dönemde, cami/türbe kapısı, pencere kapakları, vaaz kürsüsü ve sanduka yüzeyine uygulanan ahşap süslemelerde sedef, fildişi ve bağa ile yapılmış kakma tekniğine ${ }^{27}$ rastlanmak$\operatorname{tad}_{1} \mathrm{r}^{28}$. Aynı dönemde sakıflı (ahşap çatı) camilerin yapımına devam edildiği ve Mimar Sinan'ın ahşap sakıflı camilerinden 8 tanesinin günümüze bazı değişikliklerle geldiği belirtilmiştir ${ }^{29}$.

Kocaeli’nin Osmanlı dönemindeki yoğun ağaç dokusu, bölgede kolay temin edilen bir malzeme olmuştur. Bu durum bölgeye gelen seyyahların da ilgisini çekmiştir. 17. yy.'da şehri ziyaret eden Evliya Çelebi, "Şehrin doğu tarafında olanlara ă̆aç denizi denilir; insan, içinde kaybolur, göklere yükselmiş öyle ă̆açlar vardır ki, 10.000 koyun gölgelenir”30 diyerek bu durumu vurgulamıştır.

${ }^{23}$ Rüstem Bozer, “Ahşap Sanatı”, Anadolu Selçuklu ve Beylikler Dönemi Uygarllğı (Mimarlık Sanat), ed. Ali Uzay Peker vd. (Ankara: Kültür ve Turizm Bakanlı̆ğ, 2006), 2/534.

${ }^{24}$ Geniş bilgi için bk. Bozer, “Ahşap Sanatı”, 2/533-541.

${ }^{25}$ Ekrem Hakkı Ayverdi, Osmanlı Mimari Çă̆ın Menşei: Osmanlı Mimarisinin İlk Devri (İstanbul: Baha Matbaas1, 1966), 122-132.

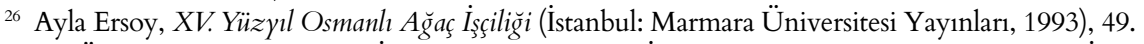

${ }^{27}$ H. Örcün Barışta, Osmanl İmparatorluğu Dönemi Istanbul Cami ve Türbelerinden Ağaç İşleri (Ankara: Atatürk Kültür Merkezi, 2009), 71.

${ }^{28}$ Geniş Bilgi İçin bk. Barışta, İstanbul Cami ve Türbelerinden A Ăaç İşleri, 71 vd.

${ }^{29}$ Aptullah Kuran, "Mimar Sinan'ın Camileri”, Mimarbaşı Koca Sinan Yaşadığı Çă̆ ve Eserleri, ed. Sadi Bayram (İstanbul: Vakıflar Genel Müdürlüğü, 1988), 189.

${ }^{30}$ Evliya Çelebi, Günümüz Türkçesiyle Evliya Çelebi Seyahatnamesi, çev. Yücel Dağl1- Seyit Ali Kahraman 2(1) (İstanbul: Yap1 Kredi Yayınları, 2005), 79. 
Kocaeli, Karamürsel Uzundere (Osmaniye) Köyü, Kafkas muhacirleri tarafindan 1877-1878 Osmanl1-Rus Savaşı sonrasında Karamürsel'de kurulan bir yerleşim yeridir. Kafkasya'dan göç eden halkın bölgede daha çok bakir ve dağlık alanlara yerleştiği bilinmektedir. Karamürsel Uzundere (Osmaniye) Köyü de aynı şekilde ormanlık bir alanda oluşturulmuş bir yerleşim yeridir. Köyün ağaç dokusunun yoğunluğu ve çeşitliliği, köy camisindeki ağaç işçiliğinin nedenini ispat eder durumdadır. Göç eden halkın geldiği yer dikkate alındığında, Kafkasya bölgesinin Osmanlı dönemi camilerinde iklim özelliklerine bağlı olarak ağaç işçiliğinin yoğun olarak uygulandığ 1 gözlemlenmektedir. Bu dönem sürecinde Kafkasya bölgesindeki tarihi camilerdeki minber, vaaz kürsüsü, tavan, mihrap gibi yapı unsurlarının ahşap malzemeli olarak benzer anlayışla süslendiği anlaşılmaktadır. Buradan hareketle, incelediğimiz cami süslemelerinin, göç edilen topraklardan bölgeye yerleşen yerel ustalar eliyle uygulanmı̧ olabileceğini söylemek mümkündür. Kocaeli ilinin Karadeniz'in batı kıyısında olması nedeniyle benzer süsleme ve tekniklere Karadeniz Bölgesi'nde de rastlanmaktadır. Burada coğrafi yakınlık ve akraba ilişkilerinin önemli payı olduğu gibi gezici ustaların (sanatçıların) bölgeler arasındaki gidiş-gelişlerini rahatça yapmasının da önemli etkisi vardır ${ }^{31}$.

Batılılaşma döneminin ekonomik ve siyasi alanındaki gelişmeleri sanatı da etkilemiş, başkent ile birlikte İmparatorluğun çeşitli eyaletlerinde dişa açılımlı bir yapı meydana getirmiştir ${ }^{32}$. Son dönemde, minber, vaaz kürsüsü, kadınlar mahfili, tavan gibi ahşap yapı elemanlarındaki ilgi çekici bezemelerin varlı̆̆ının batılılaşma etkisiyle meydana geldiği bilinmektedir ${ }^{33}$.

Karamürsel Uzundere (Osmaniye) Köyü Camii’nin ahşap süslemeleri batılılaşma döneminin özelliklerini yansıtmaktadır. Barok tarzı süslemeler ve stilize edilmiş motifler ülke genelinde sıklıkla uygulanan be-

\footnotetext{
${ }^{31}$ Selçuk Seçkin, “Gürcistan Acara Keda Bölgesi’ndeki Osmanlı Dönemi Camileri”, Turkish Studies 13/18 (2018), 1165.

${ }^{32}$ Günsel Renda, “Osmanlı Yenileşme Döneminde Kültür ve Sanat”, Türkler Ansiklopedisi (Ankara: Yeni Türkiye Yayınları, 2002), 15/453.

33 Barışta, Osmanlı Imparatorluğu Dönemi, 491-553.
} 
zemelerdir. Bu yönüyle geç dönem ahşap süsleme anlayışının bu küçük camide uygulanması oldukça önem arz etmektedir.

Çalışmamızın konusunu oluşturan Karamürsel Uzundere (Osmaniye) Köyü Camii’nin süslemenin yoğunlaştığı ahşap minber aynalığ1 ve köşk altındaki "S" kıvrımları, kıvrımlı dal ve yapraklarının benzer örnekleri, Ordu bölgesinde Derinçay Mahallesi Merkez Camii, Fizme (Ecelli) Mahallesi Büyük Camii ve Şenyurt Mahallesi Helvacıŏlu Camii örneklerinde ${ }^{34}$; Trabzon'da Bölümlü Mithat Paşa Mahallesi Camii, Su Geldi Köyü Aşağı Mahalle Camii, Yazlık Köyü Merkez Camii, Gürpınar Beldesi Hacı Bayram Mahallesi Camii ve Saraçlı Köyü Yukarı Mahalle Camii ${ }^{35}$, Sürmene Yukarı Kefeli Camii ${ }^{36}$; Samsun'da Kavak Bekdemir Köyü Camii, Çarşamba Porsuk Köyü Camiii ${ }^{37}$; Artvin'de Zeytinlik Merkez Camii, Oruçlu Camii, Ortacalar Merkez Camii, Dikyamaç Camii, Muratlı Merkez Camii, Camili Camii ve Dereköy Merkez Camii ${ }^{38}$; Rize'de Çamlıhemşin Aşağı Çamlıca Camii ve Güneyce Hacı Şeyh Camii ${ }^{39}$ örneklerinde karşımıza çıkmaktadır. Günümüzde Gürcistan sınırları içinde bulunan Acara bölgesindeki Hohna Camii, Tskmorisi Camii, Medzibna Camii ve Kveada Agara Camii'nde ${ }^{40}$ de benzer örneklere rastlanmaktadır. Trabzon Araklı Kayacık Köyü Merkez Camii örneğinde minber aynalığındaki kıvrımlı dallar benzer bir anlayışla uçları dilimli yaprakla bezenmiş olup ortasına güneş kursu yerleştirilmiştir ${ }^{41}$ (Tablo 1).

${ }^{34}$ Ahmet Ali Bayhan, Geçmişten Günümüze Ordu’nun Geleneksel Ahşap Camileri (Ordu: Ordu Büyükşsehir Belediyesi Kültür Yayınları, 2019), 215, 229, 233-234.

${ }^{35}$ Erdem Karadeniz, Trabzon Of İlçesi’ndeki Mimari Eserleri (Van: Yüzüncü Y1l Üniversitesi, Sosyal Bilimler Enstitüsü, Yüksek Lisans Tezi, 2017), 190-270.

${ }^{36}$ Mehmet Yavuz, "Sürmene Gültepe Köyü Yukarı Kefeli Mahallesi Camii ve Şadırvanı", Uluslararası Sosyal Araştırmalar Dergisi 7/31 (2014), 516.

${ }^{37}$ Mehmet Sami Bayraktar, Samsun'da Türk Devri Mimarisi (Samsun: Canik Belediyesi, 2016), 8189, 160-267.

${ }^{38}$ Osman Aytekin, Ortaçăğdan Osmanl Dönemi Sonuna Kadar Artvin'deki Mimari Eserler (Ankara: Kültür Bakanlığı Yayınları, 1999), (Resimler Bölümü-355).

${ }^{39}$ Mehmet Yavuz, "Doğu Karadeniz Köy Camilerinde Bezeme Anlayı̧ı”, Uluslararası Sosyal Araştırmalar Dergisi 2/6 (2009), 317-318.

${ }^{40}$ Seçkin, "Gürcistan Acara Keda Bölgesi'ndeki”, 1147, 1152-1155.

${ }^{41}$ Demet Taşkan, Trabzon Illi Camilerinde Ahşap Minberler (Ankara: Gazi Üniversitesi, Sosyal Bilimler Enstitüsü, Doktora Tezi, 2016), 38. 


\section{Tablo-1}

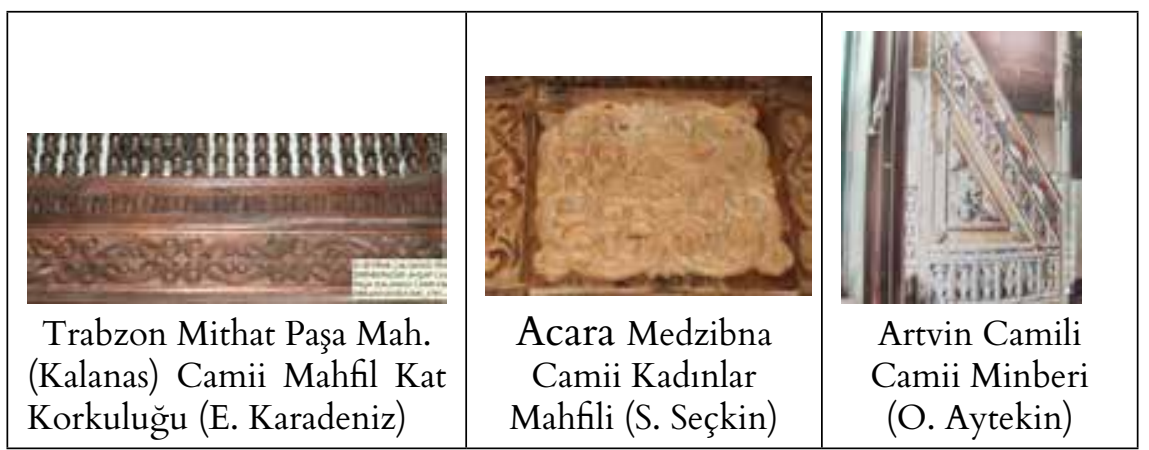

Karamürsel Uzundere (Osmaniye) Köyü Camii'ndeki köşk altında uygulanan yelpaze motifine, Acara Hulo Bölgesi'ndeki Ghorcami Camii minber aynalığında ${ }^{42}$, Samsun Asarcık Kılavuzlu Köyü Camii kapı kanatlarında ${ }^{43}$ yer verilmiştir (Tablo 2). Minber köşk altındaki ayyıldız motifleri ise, Karaağaç Köyü Camii minberinin köşk alıında ${ }^{44}$, Gürcistan-Acara Pirlevi Mağasi Camii'nin ahşap minberi üzerinde ${ }^{45}$, Ordu Gürçek Mahallesi Camii minberinde ${ }^{46}$ ve Trabzon Arsin Çatak Köyü Camii minberinin külah aleminde ${ }^{47}$ tekrarlanmaktadır.

Tablo-2

\begin{tabular}{|c|c|c|}
\hline & \\
\hline
\end{tabular}

${ }^{42}$ Selçuk Seçkin, "Farklı Plan Özellikleriyle Gürcistan Acara Hulo Bölgesi'ndeki Ghorcami Camii, MJH 8/2 (2018), 468.

${ }^{43}$ Bayraktar, Samsun'da Türk Devri, 131.

${ }^{44}$ Muhammet Özkurt, Rize Ahşap Camilerinde Süsleme (Karabük: Karabük Üniversitesi, Sosyal Bilimler Enstitüsü, Yüksek Lisans Tezi, 2020), 307.

${ }^{45}$ Seçkin, "Gürcistan Acara Keda”, 1148.

${ }^{46}$ Bayhan, Geçmişten Günümüze Ordu’nun, 153.

${ }^{47}$ Taşkan, Trabzon Ili Camilerinde, 91. 
Karamürsel Uzundere Köyü Camii'ndeki kubbenin oturduğu harim tavanının köşelerine monte edilen sivri uçlu profiller, özellikle Kocaeli camilerinde bir geleneğe dönüşmüştür. Kocaeli'nin Geç Osmanlı Dönemi ve Cumhuriyet Dönemi camilerinden; İzmit Urgancı Ahmet Çelebi Camii, Gölcük Hacı Davut Ağa Camii ve Gölcük Nüzhetiye Köyü Camii harim tavanlarında benzer olarak uygulanmıştır (Tablo 3).

Tablo -3

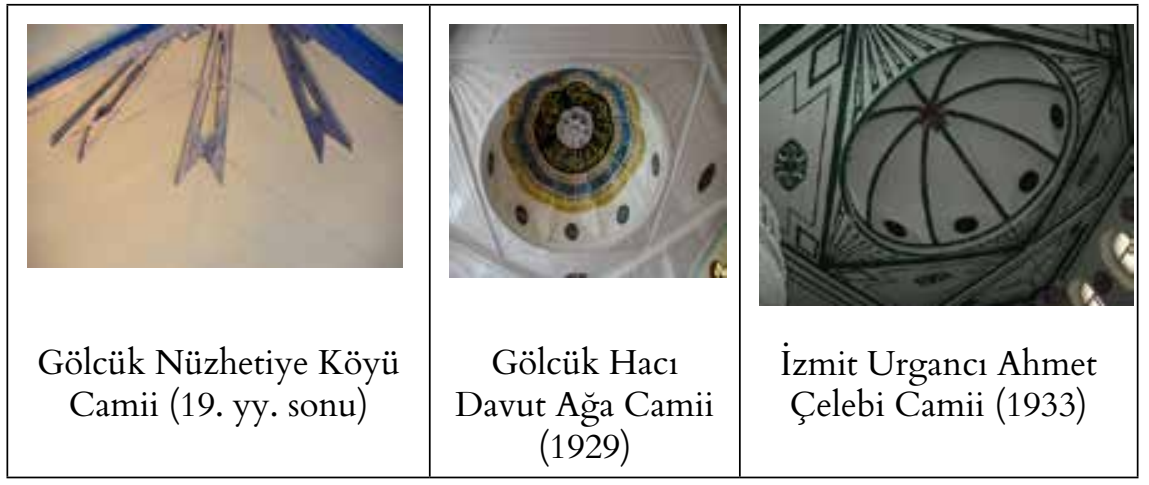

\section{Sonuç}

Karamürsel'in bilinen ilk camisi 16. yy. tarihli Kara Bâli Bey Külliyesi’ndeki yapı topluluğu içerisinde bulunmaktadır. Bölgede meydana gelen depremler Karamürsel'de de önemli ölçüde hissedilmiş ve özellikle tarihi yapıların günümüze kadar gelmesini engellemiştir. Nitekim 1719 yılında gerçekleşen İstanbul depreminden Karamürsel ve Kazıklı (Kavaklı) yerleşimlerinin ağır şekilde etkilendiği ve yapıların ağır hasar gördügü bilinmektedir ${ }^{48}$. Üsküdar hurufat defterlerini incelediğimizde Karamürsel'de 41 adet cami bulunduğu ve bunlardan 39 tanesinin günümüze gelemediği, ayrıca 1 tanesinin de Yalova ili sınırlarında kaldı$\breve{g} 1$ tespit edilmiştir. Kurtuluş Savaşı sırasında Yunanların şehri yakarak kaçtığ $1^{49}$ ve bu yangın sırasında Kara Bâli Bey Camii'nin yandığı bilinmektedir. Bu bağlamda günümüze gelemeyen camilerin ya deprem

${ }^{48}$ Orhan Sakin, Tarihsel Kaynaklara Göre İstanbul Depremleri (İstanbul: Kitabevi Yayınları, 2002), 50-51.

${ }^{49}$ Rıfat Yüce, İzmit ve Çevresel Tarihi (İzmit: İzmit Rotary Kulübü, 1998), 59. 
gibi doğal afetlerden ya da tarihteki savaş koşullarından dolayı varlıklarını koruyamadıkları düşünülebilir. Günümüzde Karamürsel ilçesinde 5 adet tarihi ve tescilli cami bulunmaktadır. Bunun haricinde Karamürsel'deki 17. yy. tarihli Valide Sultan Köprüsü ${ }^{50}$ bugün ayakta ve sağlam durumdadır. 18. yy. başındaki çeşme ve namazgâh ve 18./19. yy.'a ait 1 adet gümrük acentesi, 1 adet postane ve askeri depo ${ }^{51}$ yapılarının günümüze ulaşamadığı, fakat şehirdeki mevcudiyetleri, yapılan araştırmalar neticesinde bilinmektedir. Bölgenin zamanında bir ağaç denizi olarak adlandırıldığ ${ }^{52}$ için kerestecilik ve gemi ticareti şehrin en önemli ticari faaliyetleri arasına girmiştir. Osmanlı döneminde gerçekleştirilen imar faaliyetlerinde de şehrin bu önemli ham maddesinden yararlanılmış, camilerin ana malzemesi, örtü sistemi, yapı elemanları ahşap malzemeden imal edilmiştir. Camilerde yer alan giriş kapısı ve pencere kanatları, tavan, mihrap, minber, kadınlar mahfili ve vaaz kürsüsü gibi ahşap yapı elemanlarında kündekâri, kafes oyma (ajur), düz ve yuvarlak satıhl derin oyma, çakma ve aplike gibi teknik ve bezeme yöntemleri uygulanmıştır.

Çalışmamıza konu olan cami, 1877-1878 Osmanl1-Rus Savaşı sonucunda Kafkasya'dan göç edenler için oluşturulmuş bir göçmen köyünde yer almaktadır. Ağaç dokusu sık bulunduğu için yapıda ahşap süslemeler yoğun olarak kullanılmıştır. Burada kurulan göçmen yerleşiminin 19. yy. sonunda inşa edilen ilk camisinin doğal afet nedeniyle yıkılmış olabileceği muhtemeldir. M 1905 yılında tekrardan yapılan caminin ahşap bezemeleri Batılılaşma Dönemi'nin üslubunu göstermesi ve yakın coğrafyalarda süsleme geleneğinin devamcısı olması bakımından önemlidir. Yapının ahşap süslemeleri, daha çok Kafkasya ve Karadeniz bölgesi sınırları içinde kalan camilerdeki ahşap süslemelere yakın bir benzerlik göstermektedir. Bu yönüyle, Kafkasya’dan bölgeye göç eden yerel ustalar eliyle çalı̧̧mamıza konu olan caminin özgün ahşap süslemelerinin uygulandığını söylemek mümkündür. Bunun yanında

${ }^{50}$ Erkan Atak- Yusuf Acıŏlu, "Kocaeli’ndeki Osmanlı Dönemi Taş Köprüler”, Çanakkale Araştırmaları Türk Yılllĭgı 17/29 (2020), 65.

${ }^{51}$ Özdemir, Kaptan-ı Derya, 102.

${ }^{52}$ Besim Darkot, “İzmit”, İslam Ansiklopedisi (İstanbul: Milli Eğitim Basımevi, 1988), 5(2)/1252. 
incelediğimiz cami süslemelerinde Kafkasya Bölgesi'ndeki benzerlikler yanında göç edilen bölge nedeniyle süslemelerde kendine has yerel ifadelerin de meydana geldiği açıktır.

\section{Kaynakça}

Aslanapa, Oktay. Türk Sanatı. İstanbul: Remzi Kitabevi, 1989.

Aytekin, Osman. Ortaçă̆dan Osmanlı Dönemi Sonuna Kadar Artvin'deki Mimari Eserler. Ankara: Kültür Bakanlığ1 Yayınları, 1999.

Ayverdi, Ekrem Hakkı. Osmanlı Mimari Çă̆ın Menşei: Osmanlı Mimarisinin İlk Devri. İstanbul: Baha Matbaası, 1966.

Atak, Erkan- Acıoğlu, Yusuf. "Kocaeli’ndeki Osmanlı Dönemi Taş Köprüler”. Çanakkale Araştırmaları Türk Yıllığı 17/29 (2020), 55-86.

Barışta, H. Örcün. Osmanl İmparatorluğu Dönemi Istanbul Cami ve Türbelerinden A $\breve{g}$ aç İ̧̧leri. Ankara: Atatürk Kültür Merkezi, 2009.

Bayhan, Ahmet Ali. Geçmişten Günümüze Ordu’nun Geleneksel Ahşap Camileri. Ordu: Ordu Büyükşehir Belediyesi Kültür Yayınları, 2019.

Bayraktar, Mehmet Sami. Samsun'da Türk Devri Mimarisi. Samsun: Canik Belediyesi, 2016.

Boran, Ali. Anadolu'daki İç Kale Cami ve Mescitleri. Ankara: TTK, 2001.

Bozer, Rüstem. "Ahşap Sanatı”. Anadolu Selçuklu ve Beylikler Dönemi Uygarlı̆̆ (Mimarlı Sanat). ed. Ali Uzay Peker vd. 2/533-541. Ankara: Kültür ve Turizm Bakanlığı, 2006.

Darkot, Besim. "İzmit". İslam Ansiklopedisi. 5(2) /1251-1256. İstanbul: Milli Eğitim Basımevi, 1988.

Ersoy, Ayla. XV. Yüzyll Osmanh A ğaç Iş̧̧̧iliği. İstanbul: Marmara Üniversitesi Yayınları,1993.

Evliya Çelebi. Günümüz Türkçesiyle Evliya Çelebi Seyahatnamesi. haz. Yücel Dağlı vd. 2/(1). İstanbul: Yapı Kredi Yayınları, 2005.

Karadeniz, Erdem. Trabzon Of İlcesindeki Mimari Eserler. Van: Yüzüncü Y1l Üniversitesi, Sosyal Bilimler Enstitüsü, Yüksek Lisans Tezi, 2017.

Kaya, Mehmet- Gecili, Derya. “19.Yüzyıl Karamürsel Kazası'nın Sosyo ve Ekonomik Durumu: Temettuat Defterleri Örneği”. Uluslararası Kara- 
mürsel Alp ve Kocaeli Tarihi Sempozyum Bildirileri. ed. Haluk Selvi vd. 1/603-654. Kocaeli: Kocaeli Büyükşehir Belediyesi Yayınları, 2016.

Kuran, Aptullah. “Mimar Sinan’ın Camileri”. Mimarbaşı Koca Sinan Yaşadı̆̆ı Çă̆ ve Eserleri. ed. Sadi Bayram. 1/176-214. İstanbul: Vakıflar Genel Müdürlüğü, 1988.

Öney, Gönül. Anadolu Selçuklu Mimari Süslemesi ve El Sanatları. Ankara: Türkiye İş Bankası Kültür Yayınları, 3. Basım, 1992.

Özdemir, Erdoğan. Dünden Bugüne Karamürsel. Kocaeli: Karamürsel Belediyesi Kültür Yayınları, 2. Basım, 1994.

Özdemir, Erdoğan. Kaptan-ı Derya Karamürsel. İstanbul: Zinde Yayıncılık, 5. Basım, 2017.

Özkurt, Muhammet. Rize Ahşap Camilerinde Süsleme. Karabük: Karabük Üniversitesi, Sosyal Bilimler Enstitüsü, Yüksek Lisans Tezi, 2020.

Öztürk, Bülent. "Karamürsel'de (Bıthynı) Bir Antik Kıyı Yerleşimi: Preınetos/Presetos”. Uluslararası Karamürsel Alp ve Kocaeli Tarihi Sempozyumu. ed. Haluk Selvi vd. 1/61-82. Kocaeli: Kocaeli Büyükşehir Belediyesi Yayınları, 2016.

Ramsay, William Mitchel. Anadolu'nun Tarihi Coğrafyası. çev. M. Pektaş. İstanbul: Milli Eğitim Basımevi, 1960.

Renda, Günsel. “Osmanlı Yenileşme Döneminde Kültür ve Sanat”. Türkler Ansiklopedisi. 15/432-462. Ankara: Yeni Türkiye Yayınları, 2002.

Sağdıç, Elif. Karamürsel Osmaniye Mahallesi Osmaniye (Uzundere) Camii Sanat Tarihi Raporu. (Nisan-2019).

Sakin, Orhan. Tarihsel Kaynaklara Göre İstanbul Depremleri. İstanbul: Kitabevi Yayınlar1, 2002.

Seçkin, Selçuk. "Gürcistan Acara Keda Bölgesi’ndeki Osmanlı Dönemi Camileri”. Turkish Studies 13/18 (2018), 1134-1169.

Seçkin, Selçuk. "Farklı Plan Özellikleriyle Gürcistan Acara Hulo Bölgesi’ndeki Ghorcami Camii”. MJH. 8/2 (2018), 464-478.

Şemseddin Sami. “Karamürsel”. Kamusu'l Alam. 5/3647. İstanbul: Mihran Matbaas1, 1896.

Talay, Aydın. Eserleriple ve Hizmetleriple II. Abdülhamit. İstanbul: Ensar Neşriyat, 2016. 
Taşkan, Demet. Trabzon İli Camilerinde Ahşap Minberler. Ankara: Gazi Üniversitesi, Sosyal Bilimler Enstitüsü, Doktora Tezi, 2016.

Ulugün, Feyzullah Yavuz. "Kocaeli'de Tarihsel Göçler”. Uluslararası Akçakoca ve Kocaeli Tarihi Sempozyum Bildirileri. ed. Haluk Selvi vd. 3/12691311. Kocaeli: Kocaeli Büyükşehir Belediyesi Yayınları, 2015.

Yavuz, Mehmet. "Doğu Karadeniz Köy Camilerinde Bezeme Anlayışı”. Uluslararası Sosyal Araştırmalar Dergisi 2/6 (2009), 306-322.

Yavuz, Mehmet. "Sürmene Gültepe Köyü Yukarı Kefeli Mahallesi Camii ve Şadırvanı”. Uluslararası Sosyal Araştırmalar Dergisi 7/31 (2014), 499-515.

Yüksel, Hasan. "Kafkas Göçmen Vakıfları”. OTAM (Ankara Üniversitesi Osmanl Tarihi Uygulama ve Araştırma Merkezi Dergisi) 5 (1994), 475-490.

Yönsel, Agâh- Arkan, Şemsettin. Karamürsel. Ankara, 1972.

Yüce, Rıfat. Izmit ve Çevresel Tarihi. İzmit: İzmit Rotary Kulübü, 1998.

\section{Arşiv Kaynakları:}

V.G.M.A, Vakıflar Genel Müdürlüğü Arşivi, Defter No: 590., Sayfa No: 6, Sira No: 5.

BOA, Osmanlı Arşivi, Dahiliye Mektubi Kalemi (DH. MKT). No: 948, Gömlek No: 15.

\section{Ekler}

Ek-1 Vakfiye (V.G.M.A, Vakıflar Genel Müd. Arşivi, Defter No: 590., Sayfa No: 6, Sira No: 5).

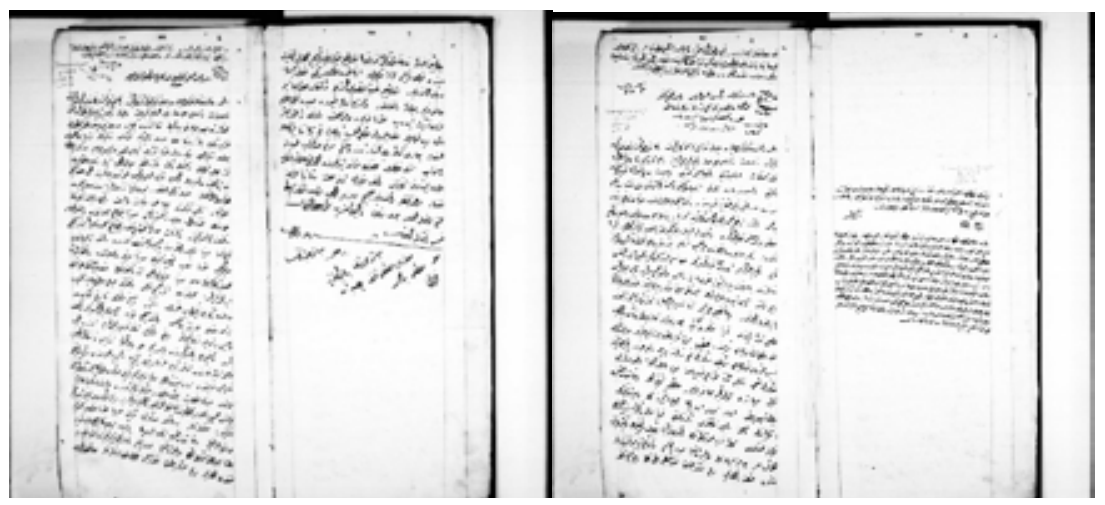


Ek-2 (BOA, Osmanlı Arşivi, Dahiliye Mektubi Kalemi (DH. MKT). No: 948, Gömlek No: 15).

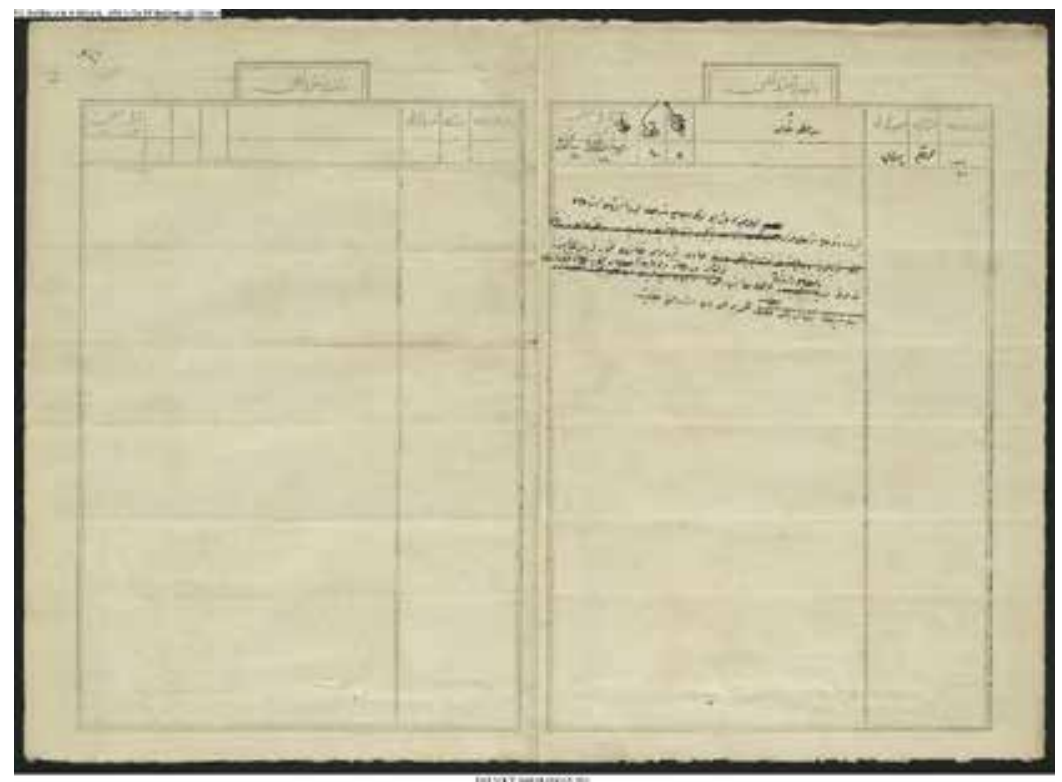

